\title{
HBV Genotype Finding
}

National Cancer Institute

\section{Source}

National Cancer Institute. HBV Genotype Finding. NCI Thesaurus. Code C157508.

The determination of the genotype of hepatitis b virus in a blood sample. 